\title{
PENGARUH MODAL INTELEKTUAL DAN TATA KELOLA PERUSAHAAN TERHADAP NILAI PERUSAHAAN MELALUI KINERJA KEUANGAN (STUDI EMPIRIS PADA PERUSAHAAN LQ45 DI BURSA EFEK INDONESIA PERIODE 2015-2017)
}

\author{
Kezia Josephine $^{1}$, Estralita Trisnawati ${ }^{2}$, Herlin Tundjung Setijaningsih ${ }^{3}$ \\ ${ }^{1}$ Program Studi Magister Akuntansi, Universitas Tarumanagara \\ Email: keziajosephine10@gmail.com \\ ${ }^{2}$ Program Studi Magister Akuntansi, Universitas Tarumanagara \\ Email: estris777@gmail.com \\ ${ }^{3}$ Program Studi Magister Akuntansi, Universitas Tarumanagara \\ Email: herlintundjung@gmail.com
}

\begin{abstract}
ABSTRAK
Saat ini investor lebih tertarik berinvestasi pada perusahaan yang memiliki harga saham yang stabil. Oleh sebab itu, penting bagi perusahaan untuk mengetahui faktor-faktor yang berpengaruh terhadap harga saham. Dalam penelitian ini terdapat dua faktor yang akan yaitu modal intelektual dan tata kelola perusahaan dengan menggunakan variabel mediasi kinerja keuangan (ROA). Penelitian ini ingin melihat pengaruh langsung dan tidak langsung antara variabel independen terhadap variabel dependen. Sampel yang digunakan dalam penelitian diambil melalui perusahaan dalam LQ 45 dengan menggunakan metode purposive sampling dalam periode waktu 2015-2017. Metode analisis data yang digunakan ialah Eviews versi 10. Hasil dari penelitian ini menemukan bahwa modal intelektual tidak berpengaruh langsumh terhadap nilai perusahaan, sedangkan tata kelola perusahaan memiliki pengaruh terhadap nilai perusahaan. Hasil penelitian ini juga menemukan bahwa terjadi pengaruh tidak langsung antara tata kelola perusahaan terhadap nilai perusahaan melalui kinerja keuangan.
\end{abstract}

Kata Kunci: Modal Intelektual, Tata Kelola Perusahaan, Kinerja Keuangan, Nilai Perusahaan.

ABSTRACT

Currently investors will be more interested in investing in companies that have a stable stock price. Therefore, it is important for the company to know the factors that affect the stock price. In this research there are two factors that will be intellectual capital and corporate governance by using variable of financial performance mediation (ROA). This study wanted to see the direct and indirect influence between the independent variables to the dependent variable. The sample used in the study was taken through the company in LQ 45 by using purposive sampling method within the period of 2015-2017. Data analysis method used is Eviews version 10. The results of this study found that intellectual capital has no direct effect on firm's value, while corporate governance has an influence on firm's value. The results of this study also found that there is an indirect influence between corporate governance on firm's value through financial performance.

Keywords: Intellectual Capital, Good Corporate Governance, Financial Performance, Firm's Value

\section{PENDAHULUAN}

\section{Latar Belakang}

Salah satu tujuan utama perusahaan didirikan adalah untuk meningkatkan kesejahteraan para pemegang saham (investor) dan stakeholder lainnya (Ulum, 2017). Langkah awal yang dapat dilakukan perusahaan untuk menarik para investor adalah dengan meningkatkan nilai perusahaan (Sukirni, 2012). Nilai perusahaan dapat dilihat melalui harga saham perusahaan tersebut. Pembentukan harga saham terjadi karena adanya permintaan dan penawaran atas saham tersebut. Perubahan harga saham disebabkan oleh dua faktor yaitu faktor eksternal dan internal perusahaan (Oktavianus, 2017). Faktor eksternal merupakan faktor yang sulit dikendalikan oleh perusahaan seperti krisis ekonomi, pengaruh unsur politik, inflasi dan sebagainya (Oktavianus, 2017). Adapun 
faktor internal adalah faktor yang timbul dari dalam perusahaan seperti kinerja perusahaan, proyeksi keuangan, serta efektifitas dan efisiensi perusahaan dalam mencapai tujuannya (Firdausi \& Riduwan, 2017). Oleh sebab itu, untuk memenuhi tujuan utama perusahaan diperlukan pengukuran kinerja yang mengambarkan aktivitas serta prestasi perusahaan. Dalam penelitian ini faktor yang akan diteliti ialah modal intelektual dan tata kelola perusahaan.

Modal intelektual merupakan aktivitas manajer yang dapat diatribusikan dalam upaya atas nama pengetahuan. Jika dikaitkan dengan perkembangan ekonomi global saat ini, telah muncul banyak industri berbasis pengetahuan yang mendorong perusahaan untuk meningkatkan nilai perusahaan ke arah strategi bisnis berdasarkan pengetahuan (knowledge based business). Penelitian mengenai modal intelektual menemukan bahwa modal intelektual memiliki pengaruh signifikan terhadap earning per share dan peningkatan modal intelektual mampu meningkatkan nilai perusahaan. Meskipun modal intelektual sulit untuk dilihat dan dikuantifikasikan, hasilnya akan tetap tercermin dalam produktivitas, efisiensi dan profitabilitas perusahaan yang menjadi lebih besar (Berzkalne \& Zelgavle, 2013; Ranani dan Bijani, 2014; Ornek \& Ayas, 2015; Cleary \& Quinn, 2016; Musadiq \& Iqbal, 2016). Namun, hasil yang berbeda ditemukan oleh Frykman \& Tolleryd (2010), dimana modal intelektual yang memuat aset non-keuangan perusahaan tidak tercermin dalam neraca. Hal ini dikarenakan adanya kesenjangan yang besar antara nilai pasar dengan nilai buku yang diungkapkan perusahaan. Selain itu, laporan keuangan dinilai gagal untuk mengungkapakn hidden value dari modal intelektual dalam laporan tahunan (Cuozzo et al., 2016).

Faktor selanjutnya ialah tata kelola perusahaan, dimana tata kelola perusahaan menjadi menarik perhatian, jika dikaitkan dengan banyak kasus yang menyebabkan ambruknya suatu perusahaan dan skandal bisnis yang terjadi di berbagai negara (Effendi, 2016). Munculnya berbagai skandal akuntansi yang terjadi pada perusahaan-perusahaan telah mengakibatkan turunnya kepercayaan publik terutama investor terhadap pelaporan keuangan yang disajikan oleh perusahaan (Hermiyetti dan Alhamra, 2016). Penelitian mengenai tata kelola perusahaan menemukan bahwa, tata kelola perusahaan memiliki pengaruh signifikan terhadap nilai perusahaan, dimana penerapan tata kelola perusahaan tercermin melalui adanya pengelolaan yang lebih demokratis, transparan, dan tanggung jawab yang akhirnya mampu meningkatkan kepercayaan investor dan meningkatkan nilai perusahaan (Gozali, 2012; Suhartanti \& Asyik, 2015; Nkundananyanga, 2016;). Adapun hasil yang berbeda membuktikan bahwa tata kelola perusahaan tidak memiliki pengaruh signifikan terhadap nilai perusahaan. Selain itu, semakin baik penerapan tata kelola perusahaan, hal tersebut memberikan manfaat yang terbatas terhadap peningkatan nilai perusahaan (Gupta \& Sharma, 2014; Arora \& Sharma, 2016; Siswanti, 2016).

Melihat masih terdapat gap dalam hasil penelitian terdahulu, maka diperkirakan terdapat variabel lain yang memengaruhi modal intelektual dan tata kelola perusahaan terhadap nilai perusahaan, yaitu kinerja keuangan sebagai variabel mediasi. Hal ini sejalan dengan penelitian yang dilakukan oleh Nuryaman (2015) yang meneliti tentang kinerja keuangan sebagai variabel mediasi antara modal intelektual terhadap nilai perusahaan. Oleh sebab itu, penelitian ini akan menggunakan kinerja keuangan sebagai variabel mediasi. Kinerja keuangan sering diukur dengan menggunakan analisis rasio keuangan yaitu rasio likuiditas, rasio solvabilitas, dan rasio profitabilitas (Fahmi, 2014). Disamping itu, informasi yang berhubungan dengan kinerja atau kondisi perusahaan umumnya ditunjukkan dalam laporan keuangan. Analisis rasio keuangan yang digunakan dalam penelitian ini ialah Return On Assets (ROA). ROA mampu menghitung kekayaan perusahaan melalui kepemilikan aset yang dapat diperoleh bukan hanya melalui modal saja, namun juga dari hutang perusahaan. Berdasarkan pemaparan yang telah dijelaskan sebelumnya, maka motivasi dalam penelitian ini 
adalah untuk melakukan penelitian yangberfokus terhadap nilai perusahaan dengan menggabungkan variabel independen yaitu tata kelola perusahaan dan modal intelektual sebagai faktor yang memengaruhi nila perusahaan melalui kinerja keuangan.

\section{Kajian Teori}

\section{Signalling Theory}

Signalling Theory pada dasarnya concern dengan penurunan asimetri informasi di antara dua pihak (Arkelof, 1970). Asimetri informasi kemudian dikembangkan oleh Spence (1973) dalam model keseimbangan sinyal yang menunjukkan bahwa asimetri informasi dapat dikurangi jika pihak yang memiliki informasi dapat mengirim sinyal kepada pihak terkait. Sebuah sinyal dapat menjadi suatu tindakan yang dapat diamati, atau struktur yang diamati, yang digunakan untuk menunjukkan karakteristik tersembunyi (atau kualitas) dari signaler tersebut. Teori persinyalan menyatakan bahwa perusahaan berkualitas tinggi akan cenderung memberikan sinyal keunggulan mereka kepada pasar melalui informasi yang dipublikasikan. Menurut Jogiyanto (2013), informasi yang dipublikasikan dapat dijadikan sebagai suatu pengumuman yang akan memberikan sinyal bagi investor dalam pengambilan keputusan investasi. Pada satu sisi, sinyal akan membuat investor dan pemangku kepentingan yang lain menaikan nilai perusahaan, dan kemudian membuat keputusan yang lebih menguntungkan bagi perusahaan (Whiting dan Miller, 2008). Sebaliknya perusahaan dengan kapasitas tidak terlalu bagus akan cenderung untuk mengungkapkan informasi yang sifatnya mandatory. Signalling theory memberikan dasar untuk memprediksi bagaimana nilai pasar saham akan bereaksi (Bergh \& Gibbons, 2011). Teori persinyalan menyarankan agar perusahaan dengan kualitas tinggi harus memberikan sinyal keunggulan kepada pasar. Pentingnya sinyal informasi dikarenakan informasi menyajikan hal-hal yang terjadi dalam perusahaan baik pada masa lalu, masa kini, maupun untuk memprediksi masa yang akan datang. Selain itu, informasi tersebut juga penting untuk mengetahui pasaran saham yang dimiliki.

Berdasarkan teori yang telah diuraikan tersebut, maka kerangka pemikiran dalam penelitian ini adalah sebagai berikut:

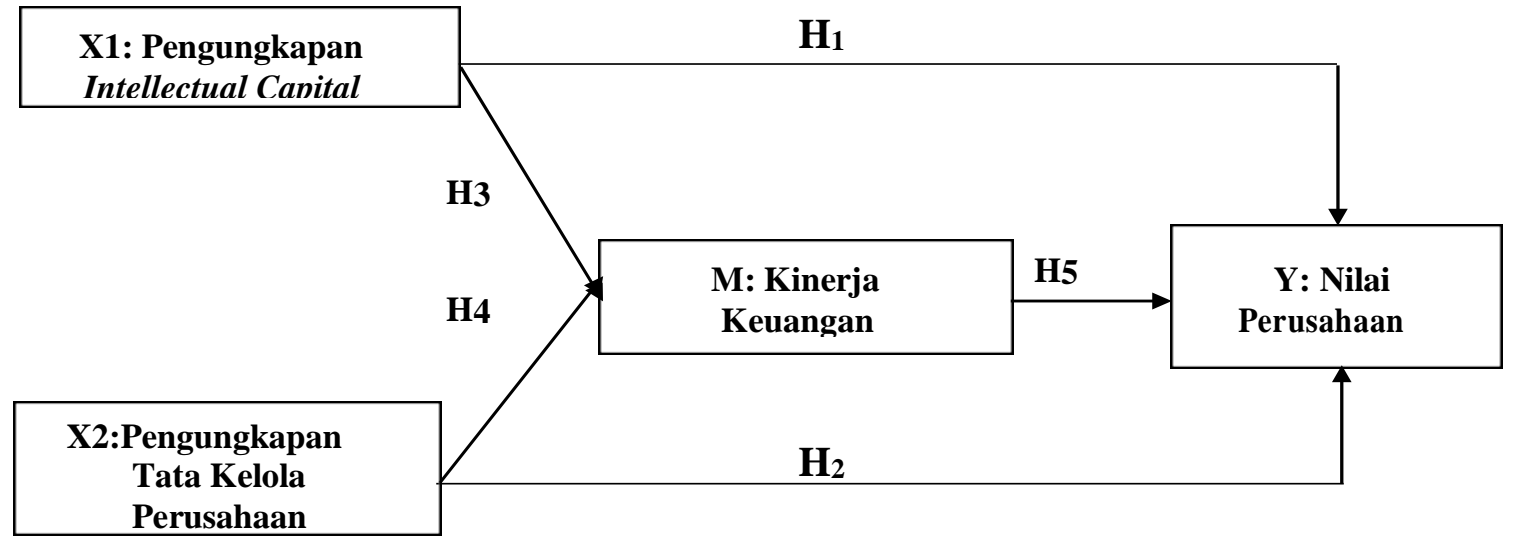

\section{H1: Pengaruh Pengungkapan Modal Intelektual Terhadap Nilai Perusahaan}

Nilai perusahaan bukan hanya berbicara mengenai perolehan laba saja, namun juga mengenai upaya yang maksimal untuk menaikkan harga saham. Harga saham merupakan cerminan baik atau buruknya suatu perusahaan di mata investor. Informasi mengenai harga saham baik secara langsung maupun tidak langsung tercermin melalui laporan tahunan dan pengungkapan lainnya. Saat ini, investor tidak hanya tertarik dengan informasi keuangan saja namun juga informasi terkait non keuangan perusahaan seperti pengungkapan modal intelektual (ICD). Selain itu, ICD menjadi salah satu informasi yang penting terkait dengan kemampuan perusahaan dalam mengelola pengetahuan 
intelektual untuk meningkatkan harga saham. Investor mempercayai bahwa manajemen pengetahuan dalam perusahaan memiliki fokus lebih detil pada aktivitas- aktivitas IC, secara dominan mengenai pemaksimalan dan pembaharuan asset-asset intelektual yang bernilai bagi perusahaan. Selain itu, melalui ICD memungkinkan bagi investor dan stakeholder lainnya untuk lebih baik dalam menilai kemampuan perusahaan di masa depan, melakukan penilaian yang tepat terhadap perusahaan dan mengurangi persepsi risiko.

\section{H2: Pengaruh Pengungkapan Tata Kelola Perusahaan Terhadap Nilai Perusahaan}

Nilai perusahaan yang tercermin melalui harga saham menjadi salah satu mekanisme penilaian dalam penerapan tata kelola perusahaan. Pengungkapan tata kelola perusahaan merupakan hal penting dan menjadi salah satu kewajiban bagi perusahaan untuk memenuhi kebutuhan informasi bagi investor. Pengungkapan tata kelola perusahaan tidak hanya bermanfaat bagi investor saja, namun juga bermanfaat untuk menarik minat investor agar berinvestasi dalam suatu perusahaan dan meningkatkan harga saham. Perusahaan yang memiliki tata kelola perusahaan yang baik cenderung memiliki nilai perusahaan yang tinggi, memiliki peluang investasi yang lebih banyak, dan pertumbuhan ekonomi yang tinggi. Pengungkapan di dalam laporan tahunan merupakan salah satu sinyal yang dapat dipercaya. Hal ini dikarenakan pengungkapan yang memadai, dapat meyakinkan investor bahwa pengelolaan perusahaan oleh manajemen dilakukan secara bijaksana dan hati- hati. Lebih lanjut, pengungkapan yang memadai juga dapat memfasilitasi investor dan membatasi manajer menyalahgunakan sumber daya perusahaan serta dapat mengawasi perilaku oportunistik manajer. Selain itu, hanya dengan pengelolaan yang baik dan maksimal atas seluruh potensi inilah, perusahaan akan dapat menciptakan value added untuk kemudian meningkatkan nilai perusahaan yang merupakan orientasi para stakeholder dalam mengintervensi manajemen.

\section{H3: Pengaruh Pengungkapan Modal Intelektual Terhadap Kinerja Keuangan}

Kinerja keuangan perusahaan merupakan salah satu hal yang menarik perhatian investor untuk mengukur seberapa efektif perusahaan dalam menggunakan kekayaan yang dimiliki untuk memperoleh laba. Kinerja keuangan sering di ukur dengan menggunakan rasio profitabilitas. Dalam penelitian ini rasio profitabilitas yang akan digunakan adalah ROA. ROA mampu memberikan informasi mengenai kemampuan perusahaan dalam menghasilkan tingkat pengembalian dan pengukuran tingkat efisiensi serta efektivitas dari aktivitas operasional perusahaan. ROA juga menunjukkan penggunaan asset yang dimiliki perusahaan dalam pengkreasian nilai perusahaan. Selain itu, informasi mengenai hal-hal yang memengaruhi kinerja keuangan tersebut dapat diungkapkan melalui laporan tahunan yang di dalamnya memuat tentang ICD. ICD memberikan informasi berupa pernyataan, catatan mengenai pernyataan, dan tambahan pengungkapan informasi yang terkait dengan catatan peningkatan kinerja keuangan.

\section{H4: Pengaruh Pengungkapan Tata Kelola Perusahaan Terhadap Kinerja Keuangan}

Kinerja keuangan adalah hasil dari banyak keputusan yang dibuat secara terus menerus oleh pihak manajemen perusahaan untuk mencapai suatu tujuan tertentu secara efektif dan efisien. Kinerja keuangan perusahaan yang meningkat seringkali dikaitkan dengan kemampuan perusahaan dalam mengelola internal perusahaan itu sendiri. Hal ini dikarenakan pengelolaan yang baik akan memberikan citra perusahaan yang baik dan meningkatkan tingkat kepercayaan investor terhadap perusahaan, terlebih ketika perusahaan mampu melalukan pengungkapan informasi yang luas dan memadai terkait dengan pengelolaan tersebut. Pengungkapan tata kelola perusahaan merupakan salah satu tolok ukur untuk melihat keunggulan kompetitif yang ada, dimana perusahaan dapat mengalahkan pesaing-pesaingnya melalui pemaparan informasi mengenai kemampuan perusahaan dalam mengelola internal perusahaan dan menguasai pangsa pasar. Adanya pangsa pasar yang baik 
akan membawa angin segar bagi kinerja keuangan perusahaan, baik untuk saat ini maupun di masa yang akan datang.

\section{H5: Pengaruh Kinerja Keuangan Terhadap Nilai Perusahaan}

Nilai perusahaan yang tercermin melalui harga saham memberikan gambaran bahwa semakin tinggi harga saham perusahaan maka akan memberikan dampak positif terhadap kemakmuran pemegang saham. Harga saham perusahaan memiliki kaitan yang erat dengan kinerja keuangan dalam perusahaan tersebut. Hal ini dikarenakan sebelum melakukan investasi, para investor akan melakukan evaluasi terhadap perusahaan yang akan menjadi tempat investasinya. Evaluasi tersebut dapat dilakukan dengan melihat rasio keuangan dengan memanfaatkan laporan keuangan perusahaan tersebut. Informasi kinerja keuangan perusahaan seringkali disebut sebagai salah satu pemicu earning power. Earning power merupakan kemampuan suatu perusahaan untuk memperoleh laba dari asset yang dimiliki dalam penelitian ini ialah ROA. ROA memegang peranan yang luas dan menjadi sinyal dalam memengaruhi pengambilan keputusan investor. Semakin tinggi ROA yang dimiliki perusahaan, maka semakin tinggi harga saham perusahaan tersebut. Hal ini sejalan dengan tujuan utama investor yaitu mendapatkan keuntungan yang maksimal, sehingga investor tidak akan melakukan investasi jika investasi tersebut merugikan.

\section{METODE PENELITIAN}

Metode yang digunakan dalam penelitian ini adalah metode kuantitatif dan kausal. Penelitian ini bertujuan untuk melihat pengaruh variabel independen (modal intelektual dan tata kelola perusahaan) terhadap variabel dependen (nilai perusahaan), dengan dimediasi oleh kinerja keuangan. Penelitian ini menggunakan unit analisis laporan tahunan atas perusahaan-perusahaan yang berada di Indonesia. Populasi yang digunakan dalam penelitian ini berasal dari perusahaan yang terdaftar dalam LQ45 dengan dimensi waktu yang diterapkan tiga tahun atau dalam penelitian ini adalah panel data, yang berarti sampel penelitian menggunakan data dari perusahaan yang diperoleh dalam beberapa periode beruntun yang mana dalam penelitian ini adalah tahun 20152017. Pemilihan sampel dalam penelitian ini menggunakan purposive sampling.

Penelitian ini terdiri dari satu variabel dependen yaitu nilai perusahaan yang diukur dengan menggunakan rumus Tobin's $q$. Sedangkan dua variabel independen dalam penelitian ini yaitu modal intelektual dan tata kelola perusahaan akan diukur dengan menggunakan content analysis. Selain itu, variabel mediasi dalam penelitian ini yaitu kinerja keuangan akan diukur dengan menggunakan ROA. Teknik analisis data yang digunakan dalam penelitian ini adalah analisis kuantitatif dengan menggunakan suatu software statistik yaitu Eviews 10. Adapun analisis data yang akan dilakukan dalam penelitian ini adalah analisis statistik deskriptif, uji koefisien determinasi $\left(\mathrm{R}^{2}\right)$, goodness of fit, uji signifikan parameter individual (uji t), dan uji sobel.

\section{HASIL DAN PEMBAHASAN Hasil Uji Statistik (Statistik Deskriptif)}

Tabel 1

Statistik Deskriptif

Sumber : data diolah

\begin{tabular}{|c|c|c|c|c|}
\hline Variabel & Mean & Maximum & Minimum & Std. Dev. \\
\hline NP & 2,820414 & 23,28575 & 0,672403 & 3,864775 \\
\hline ICD & 0,776051 & 0,944444 & 0,456522 & 0,109766 \\
\hline GCGD & 0,587133 & 0,860335 & 0,251397 & 0,136942 \\
\hline ROA & 0,097273 & 0,458000 & 0,010000 & 0,097988 \\
\hline
\end{tabular}


Nilai NP yang telah dihitung dengan menggunakan rumus Tobin's $q$ memiliki nilai rata-rata atau mean sebesar 2,820414. Jika dibandingkan dengan nilai deviasi standar sebesar 3,864775, NP berada pada posisi lebih besar dari satu $(>1)$, hal ini membuktikan bahwa perusahaan dinilai 2 hingga 3 kali lipat lebih besar oleh investor dari nilai buku perusahaan tersebut. Hasil ICD menunjukkan bahwa rata-rata perusahaan dalam sampel penelitian ini telah melakukan pengungkapan modal intelektual sebanyak $77,6 \%$ dari total pengungkapan yang seharusnya. Sebesar $58,71 \%$ menunjukkan bahwa perusahaan melakukan pengungkapan sesuai dengan komponen dalam ACGS. Rata-rata nilai ROA menunjukkan bahwa perusahaan dalam sampel penelitian ini mampu menghasilkan laba bersih sebesar 9,72\% dari total aset yang dimiliki perusahaan.

\section{Uji Koefisien Determinasi $\left(\mathbf{R}^{2}\right)$}

Tabel 2

Hasil Uji Koefisien Determinasi $\left(\mathrm{R}^{2}\right)$

Sumber: Hasil Olahan Eviews

\begin{tabular}{lrlll}
\hline \hline \multicolumn{1}{c}{ Variable } & Coefficient & Std. Error & z-Statistic & Prob. \\
\hline \hline ICD & 1.688391 & 0.407745 & 4.140797 & 0.0000 \\
GCGD & 0.673739 & 0.538882 & 1.250253 & 0.2112 \\
\hline \hline \multicolumn{5}{c}{ Robust Statistics } \\
\hline \hline R-squared & -1.221467 & 0.431941 & -2.827852 & 0.0047 \\
Rw-squared & 0.031937 & Adjusted R-squared & 0.010424 \\
Akaike info criterion & 0.113883 & Adjust Rw-squared & 0.113883 \\
Deviance & 164.6869 & Schwarz criterion & 174.7952 \\
Rn-squared statistic & 48.36126 & Scale & 0.547734 \\
\hline \hline & 8.061439 & Prob(Rn-squared stat.) & 0.017762 \\
\hline \hline & Non-robust Statistics \\
\hline Mean dependent var & 2.820414 & S.D. dependent var & \\
S.E. of regression & 4.156095 & Sum squared resid & 1554.5847 \\
\hline \hline
\end{tabular}

Tampilan output eviews pada tabel 2 menunjukkan besarnya $R w$-squared sebesar 0,11382 . Hal ini berarti 11,38\% variasi nilai perusahaan dapat dijelaskan melalui dua variabel independen ICD dan GCGD, sedangkan sisanya sebesar 88,62\% (100\%-11,38\%) dijelaskan oleh variabel lain di luar model yang tidak diteliti dalam penelitian ini.

\section{Goodness of Fit}

Tabel 3

Goodness of Fit

Sumber : Hasil Olahan Eview

\begin{tabular}{lrlll}
\hline \hline \multicolumn{1}{c}{ Variable } & Coefficient & Std. Error & z-Statistic & Prob. \\
\hline \hline IC & 1.688391 & 0.407745 & 4.140797 & 0.0000 \\
GCGD & 0.673739 & 0.53882 & 1.250253 & 0.2112 \\
& -1.221467 & 0.431941 & -2.827852 & 0.0047 \\
\hline \hline \multicolumn{5}{c}{ Robust Statistics } \\
\hline \hline R-squared & 0.031937 & Adjusted R-squared & 0.010424 \\
RW-squared & 0.113883 & Adjust Rw-squared & 0.113883 \\
Akaike info criterion & 164.6869 & Schwarz criterion & 174.7952 \\
Deviance & 48.36126 & Scale & 0.547734 \\
Rn-squared statistic & 8.061439 & Prob(Rn-squared stat.) & 0.017762 \\
\hline \hline \multicolumn{5}{c}{ Non-robust Statistics } \\
\hline \hline Mean dependent var & 2.820414 & S.D. dependent var \\
S.E. of regression & 4.156095 & Sum squared resid & 3.864775 \\
\hline \hline
\end{tabular}

Berdasarkan tabel output Eviews pada tabel 3 diperoleh nilai signifikansi Prob(Rn-squared stat.) sebesar 0,017762 lebih kecil dari 0,05. Oleh sebab itu dapat disimpulkan bahwa secara simultan atau bersama- sama variabel independen ICD dan GCGD memiliki pengaruh signifikan terhadap nilai perusahaan atau model tersebut layak untuk diteliti. 


\title{
Uji Signifikan Parameter Individual (Uji t)
}

\author{
Tabel 4
}

Uji Hipotesis Variabel Independen terhadap Variabel Dependen Sumber: Hasil Olahan Eviews

\begin{tabular}{|c|c|c|c|c|}
\hline Variable & Coefficient & Std. Error & z-Statistic & Prob. \\
\hline c & 0.021464 & 0.033096 & 0.648546 & 0.5166 \\
\hline ICD & 0.074466 & 0.043740 & 1.702464 & 0.0887 \\
\hline GCGD & -0.021754 & 0.035060 & -0.620465 & 0.5350 \\
\hline \multicolumn{5}{|c|}{ Robust Statistics } \\
\hline R-squared & 0.010724 & \multicolumn{2}{|c|}{ Adjusted R-squared } & -0.011260 \\
\hline Rw-squared & 0.032833 & \multicolumn{2}{|c|}{ Adjust Rw-squared } & 0.032833 \\
\hline Akaike info criterion & 116.1635 & \multicolumn{2}{|c|}{ Schwarz criterion } & 126.5155 \\
\hline Deviance & 0.278327 & \multicolumn{2}{|l|}{ Scale } & 0.049647 \\
\hline Rn-squared statistic & 2.898515 & \multicolumn{2}{|c|}{ Prob(Rn-squared stat.) } & 0.234745 \\
\hline \multicolumn{5}{|c|}{ Non-robust Statistics } \\
\hline Mean dependent var & 0.097273 & \multirow{2}{*}{\multicolumn{2}{|c|}{$\begin{array}{l}\text { S.D. dependent var } \\
\text { Sum squared resid }\end{array}$}} & 0.097988 \\
\hline S.E. of regression & 0.104779 & & & 0.988085 \\
\hline
\end{tabular}

Berdasarkan hasil output Eviews pada tabel 4 menunjukkan bahwa ICD memiliki nilai koefisien sebesar 0,673739 dan nilai t hitung sebesar 1,25025 lebih kecil daripada t tabel yaitu 1,98552. ICD juga mempunyai nilai signifikansi sebesar 0,2112 dimana nilai signifikansi lebih besar dari 0,05, sehingga hal ini membuktikan bahwa ICD tidak berpengaruh terhadap nilai perusahaan. Namun, hasil output Eviews pada tabel 4 juga menunjukkan bahwa GCGD memiliki nilai koefisien 1,221467 dan nilai t hitung sebesar -2,82785 lebih kecil daripada t tabel sebesar 1,9852 dengan nilai signifikansi sebesar 0,0047, sehingga hal ini membuktikan bahwa GCGD memiliki pengaruh signifikan terhadap nilai perusahaan.

Tabel 5

Uji Hipotesis Variabel Independen terhadap Variabel Mediasi Sumber: Hasil Olahan Eviews

\begin{tabular}{lrlll}
\hline \hline \multicolumn{1}{c}{ Variable } & Coefficient & Std. Error & z-Statistic & Prob. \\
\hline \hline ICD & 0.021464 & 0.033096 & 0.648546 & 0.5166 \\
GCGD & 0.074466 & 0.043740 & 1.702464 & 0.0887 \\
\hline \hline \multicolumn{5}{c}{ Robust Statistics } \\
\hline \hline R-squared & -0.021754 & 0.035060 & -0.620465 & 0.5350 \\
Rw-squared & 0.010724 & Adjusted R-squared & -0.011260 \\
Akaike info criterion & 0.032833 & Adjust Rw-squared & 0.032833 \\
Deviance & 116.1635 & Schwarz criterion & 126.5155 \\
Rn-squared statistic & 0.278327 & Scale & 0.049647 \\
\hline \hline & 2.898515 & Prob(Rn-squared stat.) & 0.234745 \\
\hline \hline & Non-robust Statistics \\
\hline Mean dependent var & 0.097273 & S.D. dependent var & 0.097988 \\
S.E. of regression & 0.104779 & Sum squared resid & 0.988085 \\
\hline \hline
\end{tabular}

Berdasarkan hasil output Eviews pada tabel 5 menunjukkan bahwa ICD memiliki nilai koefisien sebesar 0,074466 dan nilai t hitung sebesar 1,70246 lebih kecil daripada t tabel yaitu 1,98552. ICD juga mempunyai nilai signifikansi sebesar 0,0887 yang mana nilai tersebut lebih besar dari 0,05, sehingga hal ini mengakibatkan hipotesis ditolak dan membuktikan bahwa ICD tidak berpengaruh terhadap ROA. GCGD memiliki nilai koefisien -0,021754 dan nilai t hitung sebesar -0,62027 lebih kecil daripada $t$ tabel sebesar 1,9852. GCGD memiliki nilai signifikansi sebesar 0,5350 yang mana nilai tersebut lebih besar daripada 0,05 . Sehingga hal ini mengakibatkan hipotesis ditolak dan GCGD tidak berpengaruh terhadap ROA. 
Tabel 6

Uji Hipotesis Variabel Mediasi terhadap Variabel Dependen

Sumber: Hasil Olahan Eviews

\begin{tabular}{|c|c|c|c|c|}
\hline Variable & Coefficient & Std. Error & z-Statistic & Prob. \\
\hline $\mathrm{C}$ & 0.707297 & 0.056584 & 12.49995 & 0.0000 \\
\hline $\mathrm{ROA}$ & 14.04071 & 0.410930 & 34.16816 & 0.0000 \\
\hline \multicolumn{5}{|c|}{ Robust Statistics } \\
\hline R-squared & 0.216941 & \multicolumn{2}{|c|}{ Adjusted R-squared } & 0.208336 \\
\hline Rw-squared & 0.798025 & \multicolumn{2}{|c|}{ Adjust Rw-squared } & 0.798025 \\
\hline Akaike info criterion & 168.1441 & \multicolumn{2}{|c|}{ Schwarz criterion } & 174.7004 \\
\hline Deviance & 24.14318 & \multicolumn{2}{|l|}{ Scale } & 0.381787 \\
\hline Rn-squared statistic & 1167.463 & \multicolumn{2}{|c|}{ Prob(Rn-squared stat.) } & 0.000000 \\
\hline \multicolumn{5}{|c|}{ Non-robust Statistics } \\
\hline Mean dependent var & 2.820414 & \multirow{2}{*}{\multicolumn{2}{|c|}{$\begin{array}{l}\text { S.D. dependent var } \\
\text { Sum squared resid }\end{array}$}} & 3.864775 \\
\hline S.E. of regression & 2.843501 & & & 735.7804 \\
\hline
\end{tabular}

Berdasarkan hasil output Eviews pada tabel 6 menunjukkan bahwa ROA memiliki nilai koefisien 14,04071 dan nilai t hitung sebesar 34,1681 lebih besar dari t tabel yaitu 1,98552. ROA juga memiliki nilai signifikansi sebesar 0,0000 yang mana nilai tersebut lebih kecil dari 0,05, sehingga hal ini mengakibatkan hipotesis diterima dan membuktikan bahwa ROA berpengaruh signifikan terhadap nilai perusahaan.

Tabel 7

Uji Sobel

Sumber: Data diolah

\begin{tabular}{|l|l|c|}
\hline \multirow{2}{*}{ Variabel } & \multicolumn{2}{|c|}{ Pengaruh Langsung } \\
\cline { 2 - 3 } & Beta & Std. Error \\
\hline ICD $\rightarrow$ NP & $-5,029$ & 3,927 \\
\hline GCGD $\rightarrow$ NP & 3,701 & 3,147 \\
\hline & \multicolumn{2}{|c|}{ Pengaruh Tidak Langsung } \\
\hline ICD $\rightarrow$ ROA & $-0,077$ & 0,100 \\
\hline GCGD $\rightarrow$ ROA & 0,070 & 0,080 \\
\hline ROA $\rightarrow$ NP & 34,849 & 1,936 \\
\hline
\end{tabular}

Penelitian ini menggunakan variabel mediasi yaitu ROA untuk melihat pengaruh langsung dan tidak langsung antara variabel independen terhadap variabel dependen. Pengaruh langsung telah dijelaskan dalam uji signifikansi parameter individual (uji statistik t). Pengaruh tidak langsung akan dihitung dengan menggunakan standard error koefisien a dan $b$, sedangkan untuk menguji signifikansi pengaruh tidak langsung, maka akan di hitung nilai t dari koefisen ab. Adapun hasil dari perhitungan tersebut $t$ hitung ICD ke NP melalui ROA adalah sebesar -0,768 dengan tingkat signifikansi sebesar 3,493 dan t hitung GCGD ke NP melalui ROA adalah sebesar 0,872 dengan tingkat signifikansi sebesar 2,796. Keduanya memiliki nilai t hitung lebih rendah dari t tabel yaitu 1,96 dan signifikansi lebih tinggi dari 0,05, sehingga dapat disimpulkan bahwa dalam penelitian ini terjadi pengaruh mediasi.

\section{Diskusi}

Berdasarkan hasil pengujian statistik memberikan bukti bahwa ICD tidak berpengaruh terhadap peningkatan nilai perusahaan. Hasil hipotesis pada penelitian ini sejalan dengan penelitian yang dilakukan oleh Frykman \& Tolleryd (2010); Cuozzo et al., (2016) yang menemukan bahwa pengungkapan modal intelektual tidak mampu mengungkapkan secara penuh terkait dengan hidden value yang dimiliki oleh perusahaan. Namun, hasil penelitian ini tidak mendukung penelitian yang 
dilakukan oleh Cleary \& Quinn (2016); Musadiq \& Iqbal (2016) yang mengungkapan bahwa semakin tinggi modal intelektual yang dimiliki perusahaan maka semakin tinggi nilai perusahaan dimata investor. Hal ini dikarenakan semakin luas pengungkapan yang dilakukan perusahaan maka hal ini akan memicu kompetitor yang berasal dari perusahaan lain untuk mengikuti penerapan modal intelektual yang ada dalam perusahaan tersebut.

Pengungkapan tata kelola perusahaan memberikan pengaruh signifikan terhadap nilai perusahaan. Hasil hipotesis pada penelitian ini sejalan dengan penelitian yang dilakukan oleh Mutmainah (2015) yang menemukan bahwa tata kelola perusahaan berpengaruh negatif signifikan terhadap nilai perusahaan. Namun, penelitian ini tidak mendukung hasil dari penelitian yang dilakukan oleh Muryati \& Suardhika (2014) yang menemukan bahwa tata kelola perusahaan berpengaruh positif terhadap nilai perusahaan. Pengujian hasil dalam penelitian ini membuktikan bahwa luasnya pengungkapan tata kelola perusahaan tidak mampu memberikan sinyal positif terhadap investor. Jika dikaitkan dengan standar pengungkapan tata kelola yang berlaku di Indonesia seperti ACGS dan OJK (Otoritas Jasa Keuangan), keduanya memiliki banyak komponen yang sulit dipahami secara langsung mengingat bahwa tidak semua investor mengetahui secara detail maksud dan tujuan dari pengungkapan tersebut dilakukan. Sehingga hal ini akan memberikan persepsi yang berbeda- beda di antara investor.

Luasnya pengungkapan modal intelektual tidak berpengaruh terhadap ROA. Hasil hipotesis dalam penelitian ini sejalan dengan penelitian Herawati (2009) yang membuktikan bawah modal intelektual tidak memiliki peranan yang penting terhadap peningkatan ROA yang dihasilkan perusahaan. Namun, hasil penelitian ini tidak mendukung penelitian yang dilakukan oleh Bontis, et al. (2000) dan Ulum (2015) yang menemukan bahwa semakin luas pengungkapkan modal intelektual maka akan mampu meningkatkan nilai ROA pada perusahaan tersebut. Peralihan strategi bisnis berbasis pengetahuan tentu membutuhkan dana yang tidak sedikit dikarenakan perusahaan harus mengeluarkan biaya lebih untuk mengelola modal intelektual mereka seperti, memberikan pelatihan terhadap karyawan, meningkatkan kontrak-kontrak kerja yang menguntungkan, melakukan strategi pemasaran yang kreatif dan sebagainya.

Luasnya pengungkapan tata kelola perusahaan tidak berpengaruh terhadap kinerja keuangan. Hasil hipotesis dalam penelitian ini sejalan dengan penelitian yang dilakukan oleh Barus (2016) yang menemukan bahwa pengungkapan tata kelola perusahaan tidak berpengaruh terhadap ROA. Namun, hasil penelitian ini tidak mendukung penelitian yang dilakukan oleh Putra \& Fidiana, (2017) yang menyatakan bahwa pengungkapan tata kelola perusahaan berpengaruh terhadap ROA. Hal ini dikarenakan tingginya standar tata kelola perusahaan yang ditetapkan baik itu ACGS maupun OJK keduanya mengharuskan manajemen untuk memiliki kemampuan yang memadai dalam menyusun serta melaksanakan tata kelola perusahaan tersebut.

ROA memiliki pengaruh signifikan terhadap nilai perusahaan. Dimana semakin tinggi ROA maka semakin tinggi nilai perusahaan di mata investor. Hal ini membuktikan bahwa dalam mengevaluasi kinerja suatu perusahaan maka investor akan lebih tertarik melihat kinerja keuangan pada perusahaan tersebut yang tercermin melalui analisis rasio keuangan, yang mana rasio yang digunakan dalam penelitian ini ialah ROA. Hasil pengujian hipotesis dalam penelitian ini mendukung penelitian yang dilakukan oleh Imron, et al. (2013) yang membuktikan bahwa ROA berpengaruh positif signifikan terhadap nilai perusahaan. Namun penelitian ini tidak mendukung penelitian yang dilakukan oleh Tjandrakirana \& Monika (2014) yang menemukan bahwa ROA tidak berpengaruh terhadap nilai perusahaan. Ketika investor ingin melakukan investasi dan 
mengharapkan return yang tinggi maka rasio yang dapat digunakan untuk analisis ialah rasio profitabilitas.

Berdasarkan hasil analisis pengaruh tidak langsung yang di hitung dengan uji Sobel, maka luasnya pengungkapan modal intelektual tidak memengaruhi nilai perusahaan meskipun melalui ROA sebagai variabel mediasi. Penelitian ini menemukan bahwa pengungkapan yang paling banyak dilakukan oleh perusahaan berada pada bagian human capital adalah sebesar 36\%. Meskipun ketiganya memiliki komposisi yang tidak jauh berbeda, namun jika dikaitkan dengan survey yang dilakukan oleh PwC (PricewaterhouseCoopers) pada tahun 2015, sebanyak 58\% CEO (Chief Executive Officer) berencana untuk mengurangi jumlah karyawan sebagai akibat dari perkembangan teknologi atau otomatisasi selama lima hingga sepuluh tahun ke depan. Oleh sebab itu, pasar atau investor saat ini tentu akan lebih tertarik pada pengembangan teknologi yang dilakukan oleh perusahaan dengan jaringan bisnis yang luas. Dalam pengungkapan modal intelektual, pengembangan teknologi dan jaringan bisnis berada dalam komponen structural capital dan relational capital. Sehingga penelitian ini membuktikan bahwa meskipun perusahaan melakukan pengungkapan modal intelektual yang berfokus pada human capital, hal ini tidak mampu meningkatkan kinerja keuangan maupun menarik perhatian investor untuk menanamkan modalnya dalam perusahaan. Berbeda dengan modal intelektual, pengungkapan tata kelola perusahaan yang semula pada uji $\mathrm{t}$ memiliki pengaruh signifikan terhadap nilai perusahaan, namun ketika di uji kembali dengan menggunakan variabel mediasi hasil yang ditemukan ialah pengungkapan tata kelola perusahaan tidak berpengaruh terhadap nilai perusahaan. Hal ini berarti, kinerja keuangan mampu memediasi pengungkapan tata kelola perusahaan terhadap nilai perusahaan.

\section{KESIMPULAN DAN SARAN}

Penerapan modal intelektual dan tata kelola yang tepat bagi setiap perusahaan mengharuskan manajemen memiliki kemampuan dan keahlian yang memadai dalam melaksanakannya. Selain itu, perbedaan intepretasi antar investor atas pengungkapan yang dilakukan perusahaan memainkan peran yang penting terhadap peningkatan atau penurunan nilai perusahaan tersebut.

Keterbatasan dalam penelitian ini dikarenakan: (1) penelitian ini hanya menggunakan periode selama tiga tahun, yaitu 2015-2017, (2) standar pengungkapan yang digunakan belum mampu diterapkan oleh rata- rata perusahaan di Indonesia, bahkan perusahaan bluechips sekalipun. Oleh sebab itu, saran yang dapat dilakukan dalam penelitian selanjutnya adalah memperluas dan memfokuskan objek penelitian dengan menggunakan sampel seperti perusahaan manufaktur. Hal ini dikarenakan perusahaan manufaktur memiliki daya saing yang tinggi dengan pangsa pasar yang luas, sehingga perusahaan perlu selalu meningkatkan inovasi dan kreatifitas untuk menarik perhatian investor.

\section{REFERENSI}

Akerlof, A. George. (1970). The Market for "Lemons": Quality Uncertainty and the Market Mechanism. The Quarterly Journal of Economics, Vol. 84, No. 3, pp. 488-500.

Arora, Akshita dan Sharma, Chandan. (2016). Corporate Governance and Firm Performance in Developing Countries: Evidence from India. Journal of Corporate Governance, Vol. 16, Iss: 2, pp. 420-436.

ASEAN Corporate Governance Scorecard Country Reports and Assessment 2015. Belkaoui, Ahmed Riahi. (2000). Teori Akuntansi. Salemba Empat, Jakarta.

Berzkalne, Irina dan Zelgavle, Elvira. (2014). Intellectual Capital and Company Value. ProcediaSocial and Behavioral Sciences, pp. 887-896. 
Bontis, N. (2001), Assessing knowledge assets: a review of the models used to measure intellectual capital.

International Journal of Management Reviews, Vol. 3 No. 1, pp. 41-60

Bontis, N. (2002), World Congress of Intellectual Capital Readings, Butterworth Heinemann/KMCI Press, Boston, MA.

Cleary, P. And Quinn, M. (2016). Intellectual Capital and Business Performance. Journal of Intellectual Capital, Vol. 17 Iss.2 pp. 255-278.

Effendi Arief Muh. (2009). The Power of Good Corporate Governance: Teori dan Implementasi. Salemba Empat. Jakarta.

Effendi Arief Muh. (2016). The Power of Good Corporate Governance: Teori dan Implementasi Edisi 2.

Salemba Empat. Jakarta.

Fahmi, Irham. (2014). Analisis Kinerja Keuangan. Alfabeta. Bandung.

Komite Nasional Kebijakan Governance. 2012. Pedoman Good Corporate Governance Perbankan Indonesia.

KNKG Draft 09 Januari 2013.

Luthfi, Abied. (2013). Pengaruh Earning Per Share, Price Earning Ratio, Return On Asset, Debt to Equity Ratio dan Marker Value Added Terhadap Harga Saham dalam Kelompok Jakarta Islamic Index. ISSN 2252-6552.

Muryati Ni Nyoman, TS \& Suardhika, I Made S. (2014). Pengaruh Corporate Governance pada Nilai Perusahaan. Vol. 9.2. Retrieved from https://ojs.unud.ac.id/index.php/Akuntansi

Musadieq, M.A., and Iqbal, M. (2016). Pengaruh Intellectual Capital dan Organizational Value Terhadap Kinerja Perusahaan (Studi pada Karyawan PT. Semen Indonesia Tbk). Jurnal Administrasi Bisnis (JAB), Vol. 33, No. 1 April.

Mutmainah. (2015). Analisis Good Corporate Governance terhadap Nilai Perusahaan. Oktober, 2015, Vol. X, No. 2, pp, 181-195. Retrieved from http://ejournal.stiedewantara.ac.id.

Nkundabanyanga, Stephen K. (2016). Board Governance, Intellectual Capital and Firm Performance: Importance of Multiplicative Effects. Journal of Economic and Administrative Sciences, Vol. 32, Iss: 1, pp. 20-45.

Nugroho, Ahmadi.(2012).Faktor-faktor yang Mempengaruhi Intellectual Capital Disclosure. ISSN 2252- 6765. Accounting Analysis Journal. Perason Prentice Hall.

Nuryaman. (2015). The Influence of Intellectual Capital on the Firm's Value with The Financial Performance as Intervening Variable. Procedia - Social and Behavioral Sciences, pp. 292298.

Ornek, Ali S., dan Ayas, Siyret. (2015). The Relationship Between Intellectual Capital, Innovative Work Behavior and Business Performance Reflection. Procedia - Social and Behavioral Sciences, pp. 1387- 1395.

Pertiwi, T.K., dan Pratama, F.M.I. (2012). Pengaruh Kinerja Keuangan, Good Corporate Governance Terhadap Nilai Perusahaan. Jurnal Manajemen dan Kewirausahaan, Vol. 14, No. 2, pp. 118-127.

Pillai, Rekha dan Al-Malkawi, H.A.N. (2017). On The Relationship Between Corporate Governance and Firm Performance: Evidence from GCC Countries. Research in International Business and Finance.

Pulic, A \& Kolakovic, M. (2003). Value Creation Efficiency in The NewEconomy.

Putra, Robby H. \& Fidiana. (2017). Pengaruh Tata Kelola Perusahaan Terhadap Kinerja Keuangan Perusahaan. Jurnal Ilmu Riset dan Akuntansi. Agustus, 2017 Vol. 6, No. 8.

Rahayu, Maryati \& Sari, Bida. (2018). Faktor-Faktor yang Mempengaruhi Nilai Perusahaan. Ikraith-Humaniora. Maret, 2018 Vol. 2, No. 2, pp. 69-76. 
Ranani, Hossein S. dan Bijani, Zivar. (2014). The Impact of Intellectual Capital on the Financial Performance of Listed Companies in Tehran Stock Exchange. International Journal of Academic Research in Accounting Finance and Management Sciences. Vol. 4 No. 1, pp. 119-127.

Riadi, Muchlisin. (2017). Pengertian, Jenis dan Pengukuran Nilai Perusahaan. Message posted to https://www.kajianpustaka.com/2017/11/pengertian-jenis-dan-pengukuran-nilaiperusahaan.html

Riyanto, Teguh. (2015). Ini Konsep Balance Akuntansi yang Mesti Anda Pahami. Message posted tohttps://zahiraccounting.com/id/blog/ini-konsep-balance-akuntansi-yang-mesti-andapahami/

Sam'ani. (2008). Pengaruh Good Corporate Governance dan Leverage terhadap Kinerja Keuangan pada Perbankan yang Terdaftar di Bursa Efek Indonesia Tahun 2004 - 2007. Tesis. Semarang: Universitas Diponegoro.

Sarwono, Jonathan. (2016). Prosedur-Prosedur Analisis Populer Aplikasi Riset Skripsi dan Tesis dengan Eviews. Yogyakarta: Gava Media.

Scott, William. (2006). Financial and Accounting Theory. Forth Edition. Toronto.

Spence, Michael. (1973). Job Market Signalling. The Quarterly Journal of Economics, Vol. 8, No. 3, pp. 355- 374.

Sudiyatno, B. dan Puspitasari, E. (2010). Tobin's Q dan Altman-Z-Score sebagai Indikator Pengukuran Kinerja Perusahaan. Kajian Akuntansi, Februari 2010, Hal. 9-21 ISSN: 19794886.

Sukirni, Dwi.(2012). Kepemilikan Manajerial, Kepemilikan Institusional Kebijakan Deviden dan Kebijakan Hutang Analisis Terhadap Nilai Perusahaan. ISSN 2252-6765.

Sutedi, Adrian. (2012). Good Corporate Governance. Sinar Grafika. Jakarta.

Terzaghi, Muhammad Titan. (2012). Pengaruh Earning Management dan Mekanisme Corporate Governance Terhadap Pengungkapan Tanggung Jawab Sosial Perusahaan Manufaktur yang Terdaftar di Bursa Efek Indonesia. Jurnal Ekonomi dan Informasi Akuntansi (JENIUS) Vol. 2 No. 1 Januari 2012.

Tika, Moh. Pabundu. (2014). Budaya Organisasi dan Peningkatan Kinerja Perusahaan. Bumi Aksara. Jakarta. Tjandrakirana, Rina \& Monika Meva. (2014). Pengaruh Kinerja Keuangan Terhadap Nilai Perusahaan pada Perusahaan Manufaktur yang Terdaftar di Bursa Efek Indonesia. Jurnal Manajemen dan Bisnis Sriwijaya. Vol. 12, No. 1 Maret 2014.

Tobin, J., 1956. The Interest-Elasticity of Transactions Demand for Cash. Review of Economics and Statistics, 38, 241-247.

Tobin's, James, 1969. A General Equilibrium Approach to Monetary Theory. Journal of Money, Credit and Banking (February), 1229.

Ulum, Ihyaul. (2017). Intellectual Capital: Model Pengukuran, Framework Pengukuran, dan Kinerja Organisasi. UMM Press. Malang.

Yunita, Novelina.(2012). Pengaruh Modal Intelektual Terhadap Kinerja Keuangan dan Nilai Pasar. Accounting Analysis Journal. ISSN 2252-6765. 